\title{
Sistem Pakar Diagnosa Penyakit Mata Menggunakan Metode Teorema Bayes
}

\author{
Natalia Anjela Sagat ${ }^{1}$, Agus Sidiq Purnomo ${ }^{2}$ \\ 1,2Informatika, Fakultas Teknologi Informasi, Universitas Mercu Buana Yogyakarta, Indonesia \\ Email: ${ }^{1}$ nataliasagat4@gmail.com, ${ }^{2}$ sidiq@ mercubuana-yogya.ac.id
}

\begin{abstract}
Abstrak
Mata merupakan salah satu panca indra atau organ tubuh yang penting dalam menunjang keseharian khususnya dalam hal melihat. Mata juga merupakan panca indra yang sangat sensitif sehingga rentan mengalami penyakit mata. Saat ini pasien dengan gejala penyakit mata semakin meningkat. Keterbatasan jumlah tenaga ahli atau dokter spesialis mata menjadi faktor utama lamanya waktu dalam mendiagnosa penyakit mata. Selain itu, dalam pengisian data pemeriksaan penyakit mata masih menggunakan pencatatan secara manual. Sehingga dibutuhkan suatu sistem yang dapat membantu melakukan diagnosa penyakit mata dengan cepat, tepat, dan akurat. Penelitian ini bertujuan untuk membangun suatu sistem pakar yang dapat mendiagnosa penyakit mata dengan menggunakan metode teorema bayes. Hasil penelitian ini berupa kesimpulan jenis penyakit mata yang diderita berdasarkan gejala yang dipilih pasien dan telah dihitung menggunakan perhitungan bayes. Berdasarkan pada pengujian 50 data pasien, didapatkan presentase kesesuaian antara sistem dengan pakar sebesar $96 \%$ data uji.
\end{abstract}

Kata kunci: penyakit mata, sistem pakar, teorema bayes

\section{Diagnostic Expert System Of Eye Disease Using Bayes Theorem}

\begin{abstract}
The eye is one of the five senses or organs, which is very important to support everyday life, especially to provide vision. The eye is also very sensitive sense, so it is prone to eye diseases. Currently, the number of patients with symptoms of eye disease increases. The limited number of experts or ophthalmologists is the main factor that causes the diagnosis of eye diseases to take a long time. Furthermore, in filling out the eye disease examination data, manual recording is still used. Thus, it is necessary to have a system that can help diagnose eye diseases quickly, precisely, and accurately. This study aims to build an expert system that can diagnose eye diseases using the Bayes theorem method. The results of this study are in the form of conclusions about the type of eye disease suffered based on the symptoms selected by the patient and have been calculated using Bayes calculation. Based on the test of 50 patient data, the percentage of conformity between the system and the expert was $96 \%$ of the test data.
\end{abstract}

Keywords: bayes theorem, expert system, eye disease

\section{PENDAHULUAN}

Kemajuan teknologi informasi semakin berkembang disegala bidang, tak terkecuali dalam bidang medis yaitu pada pengembangan sistem pakar. Sistem pakar merupakan salah satu pemanfaatan artificial intelligence yang populer saat ini. Pemanfaatan teknologi informasi dalam sistem pakar ini digunakan untuk mendiagnosa suatu penyakit dengan meniru kinerja dari seorang dokter spesialis atau seorang ahli. Sistem pakar terdiri dari dua bagian pokok, yaitu lingkungan pengembangan dan lingkungan kosultasi. Lingkungan pengembangan digunakan sebagai pembangun sistem pakar, baik dari segi pembangunan komponen maupun basis pengetahuan. [1]. Pengembangan sistem pakar dapat digunakan pada berbagai macam penyakit, salah satunya penyakit mata. Mata merupakan suatu panca indra yang sangat penting bagi kehidupan manusia. Dalam era modern seperti saat ini, mata tidak hanya berfungsi untuk melihat dan membaca buku saja, akan tetapi dapat digunakan untuk pekerjaan-pekerjaan yang membutuhkan investigasi seperti memata-matai, mendeteksi, dan lain sebagainya [2]. Mata terusun dari jaringan organ yang sensitif sehingga sangat rentan mengalami iritasi maupun penyakit.

Penyakit mata sangat umum terjadi menyebabkan jumlah penderita penyakit mata semakin meningkat. Namun tak dapat dipungkiri bahwa pada beberapa rumah sakit dengan ketersediaan seorang tenaga ahli atau dokter spesialis mata sangat minim. Hal ini yang memicu proses mendiagnosa pasien cenderung lebih lama, sehingga waktu yang digunakan menjadi tidak efisien. Apalagi dalam beberapa kasus pada rumah sakit, pencatatan data masih menggunakan sistem secara manual sehingga data menjadi tidak terstruktur dengan baik 
Berdasarkan pada permasalahan tersebut, pada penelitian ini bertujuan untuk membangun dan mengimplementasi sistem pakar untuk mendiagnosa penyakit mata dengan menggunakan metode teorema bayes. Pengembangan sistem pakar ini menggunakan metode teorema bayes dalam mencari nilai probabilitas bayes terbesar yang kemudian akan menjadi penentu jenis penyakit mata yang derita oleh pasien. Penelitian ini berfokus dalam membantu mendiagnosa penyakit mata terutama untuk keperluan medis. Penyakit mata yang digunakan dalam penelitian ini berupa penyakit mata yang dapat dilihat secara langsung oleh mata seperti penyakit hordeolum, mata kering, episkleritis, pterygium, dan katarak.

Sistem pakar menggunakan pengetahuan khusus tentang gejala dari bermacam-macam penyakit mata. Setiap penyakit tersebut dijabarkan detail gejalanya yang didapat dari buku dan juga dari dokter spesialis mata [3]. Jika mata mengalami gangguan atau penyakit mata, maka tentunya akan berakibat fatal bagi kehidupan manusia itu sendiri. Kesibukan seorang pakar juga membuat penanganan terhadap penyakit mata tidak bisa cepat dilakukan [4].

Seiring perkembangan teknologi yang sangat pesat, pada bidang kedokteran berdampak pada pemanfaatkan teknologi untuk membantu mengatasi penyakit-penyakit yang diderita oleh masyarakat [5]. Teorema bayes adalah teorema yang digunakan dalam statistika untuk menghitung peluang suatu hipotesis. Basis pengetahuan sistem pakar diperoleh dari akuisisi pengetahuan pakar [6]. Penelitian menggunakan metode teorema bayes yang merupakan salah satu metode ketidakpastian dapat memberikan hasil diagnosa dengan nilai probabilitas kemunculan dari setiap penyakit berdasarkan pada setiap gejala di semua penyakit [7].

\section{METODE PENELITIAN}

Metode yang digunakan dalam penelitian ini adalah metode teorema bayes. Teorema bayes adalah suatu metode untuk menghasilkan estimasi parameter dengan menggabungkan informasi dari sampel dan informasi yang telah tersedia sebelumnya. Keunggulan utama dalam penggunaan metode teorema bayes adalah penyederhanaan dari cara klasik yang penuh dengan integral untuk memperoleh model marginal [8]. Probabilitas bayes merupakan salah satu cara untuk mengatasi ketidakpastian data dengan menggunakan formula bayes yang dinyatakan pada Persamaan 1.

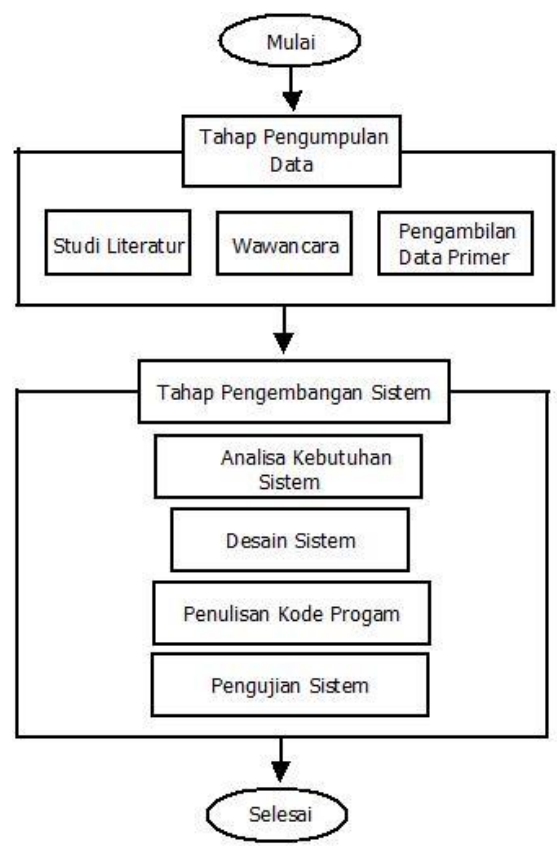

Gambar 1 Tahapan Penelitian (Sumber: Hasil Olahan Peneliti)

$$
P(H \mid E)=\frac{p(E \mid H) * p(H)}{p(E)}
$$

Jika evidence tunggal E dan hipotesis ganda H1, H2, H3, ... Hn, diartikan bahwa jumlah gejala yang sama pada beberapa penyakit [9] maka bentuk teorema bayes adalah pada Persamaan 2. 


$$
P(H i \mid E)=\frac{p(E \mid H i) \times p(H i)}{\sum_{k=1}^{n} p(E \mid H k) \times p(H k)}
$$

Dimana :

$\mathrm{P}(\mathrm{Hi} \mid \mathrm{E}) \quad=$ probabilitas hiposesis Hi benar jika diberikan evidence $\mathrm{E}$.

$\mathrm{P}(\mathrm{E} \mid \mathrm{Hi}) \quad=$ probabilitas munculnya evidence $\mathrm{E}$, jika diketahui hipotesis Hi benar.

$\mathrm{P}$ (Hi) = probabilitas hipotesis Hi (menurut hasil sebelumnya) tanpa memandang evidence apapun.

$\mathrm{N} \quad=$ jumlah hipotesis yang mungkin.

\subsection{Tahapan Penelitian}

Tahapan atau alur penelitian menjelaskan urutan penelitian yang akan dilakukan. Tahap penelitian terbagi menjadi dua bagian besar, yaitu tahap pengumpulan data serta tahap pengembangan sistem sebagai berikut : (1) Studi literatur, (2) Wanwancara, (3) Pengambilan data primer, (4) Analisis kebutuhan sistem, (5) Desain sistem, (6) Penulisan kode program, (7) Pengujian sistem. Tahapan penelitian dapat dilihat pada Gambar 1.

\subsubsection{Tahap Pengumpulan Data}

1. Studi literatur pada penelitian ini dimaksudkan guna mendapatkan gambaran mengenai objek yang diteliti. Studi literatur berasal dari buku, jurnal, maupun penelitian terkait sistem pakar, metode teorema bayes, maupun penyakit mata.

2. Wawancara adalah suatu kejadian atau proses interaksi antara pewawancara dan sumber informasi atau orang yang di wawancarai melalui komunikasi langsung [10] dalam hal ini yaitu dengan dokter spesialis mata untuk memperoleh data penelitian yang dibutuhkan.

3. Pengambilan data primer yaitu data utama penelitian berupa data penyakit mata, data gejala, data bobot, serta data rekam medis pasien. Berdasarkan pada tahap pengumpulan data, didapatkan data yang digunakan dalam penelitian ini berupa jenis penyakit mata, gejala penyakit mata, serta data rule bobot gejala terhadap penyakit yang didapatkan dari seorang pakar, dalam hal ini dokter spesialis mata. Data yang diperoleh dapat dilihat pada Tabel 1 sampai dengan Tabel 3.

Tabel 1 Penyakit Mata

\begin{tabular}{cc}
\hline Kode Penyakit & Nama Penyakit \\
\hline P01 & Hordeolum \\
P02 & Mata Kering \\
P03 & Episkleritis \\
P04 & Pterygium \\
P05 & Katarak \\
\hline
\end{tabular}

Tabel 2 Gejala Penyakit Mata

\begin{tabular}{ll}
\hline Kode Gejala & \multicolumn{1}{c}{ Nama Gejala } \\
\hline Gj01 & Muncul benjolan dikelopak mata dan kantog \\
Gj02 & Terasa mrngganjal pada mata \\
Gj03 & Rasa nyeri dan gatal pada mata \\
Gj04 & Bengkak pada mata \\
Gj05 & Mata kering seperti berpasir \\
Gj06 & Mata berair \\
Gj07 & Mata sering mengeluarkan kotoran dan \\
Gj08 & terasa lengket \\
Gj09 & Mata terasa cepat Lelah \\
Gj10 & Mata terasa pedih dan panas \\
Gj11 & Mata merah berulang \\
Gj12 & Terdapat selaput pada mata \\
Gj13 & Mata kabur seperti berkabut \\
Gj14 & Silau \\
Gj15 & Pandangan masih blur meskipun sudah \\
& berganti ukuran kacamata \\
\hline
\end{tabular}


Tabel 3 Data rule keseuaian gejala penyakit mata dengan jenis penyakit mata

\begin{tabular}{cccccc}
\hline Kode & P01 & P02 & P03 & P04 & P05 \\
Gejala & & & & \\
\hline Gj01 & $\sqrt{ }$ & & & & \\
Gj02 & $\sqrt{ }$ & & $\sqrt{ }$ & $\sqrt{ }$ & \\
Gj03 & $\sqrt{ }$ & & & & \\
Gj04 & $\sqrt{ }$ & & & & \\
Gj05 & & $\sqrt{ }$ & & & \\
Gj06 & & $\sqrt{ }$ & $\sqrt{ }$ & & \\
Gj07 & & $\sqrt{ }$ & & & \\
Gj08 & & $\sqrt{ }$ & $\sqrt{ }$ & & \\
Gj09 & & & $\sqrt{ }$ & & \\
Gj10 & & & & & \\
Gj11 & & & & $\sqrt{ }$ & \\
Gj12 & & & & $\sqrt{ }$ & $\sqrt{ }$ \\
Gj13 & & & & & $\sqrt{ }$ \\
Gj14 & & & & $\sqrt{ }$ \\
Gj15 & & & & & $\sqrt{ }$ \\
\hline
\end{tabular}

\subsubsection{Tahap Pengembangan Sistem}

1). Analisa kebutuhan sistem yaitu kebutuhan yang akan digunakan pada sistem berdasarkan sistem pakar yang akan dibangun.

2). Desain sistem yaitu kerangka atau gambaran yang akan ada dalam penelitian ini berupa desain flowchart dan data flow diagram.

a. Desain flowchart sistem merupakan alur atau tahapan ketika sistem dijalankan, yaitu berawal dengan melakukan dignosa pada pasien, menginput data pasien, memilih gejala, kemudian sistem akan menghitung dengan menggunakan metode teorema bayes, selanjutnya akan didapatkan hasil diagnosa penyakit mata yang dialami oleh pasien. Desain flowchart sistem dapat dilihat pada Gambar 2.

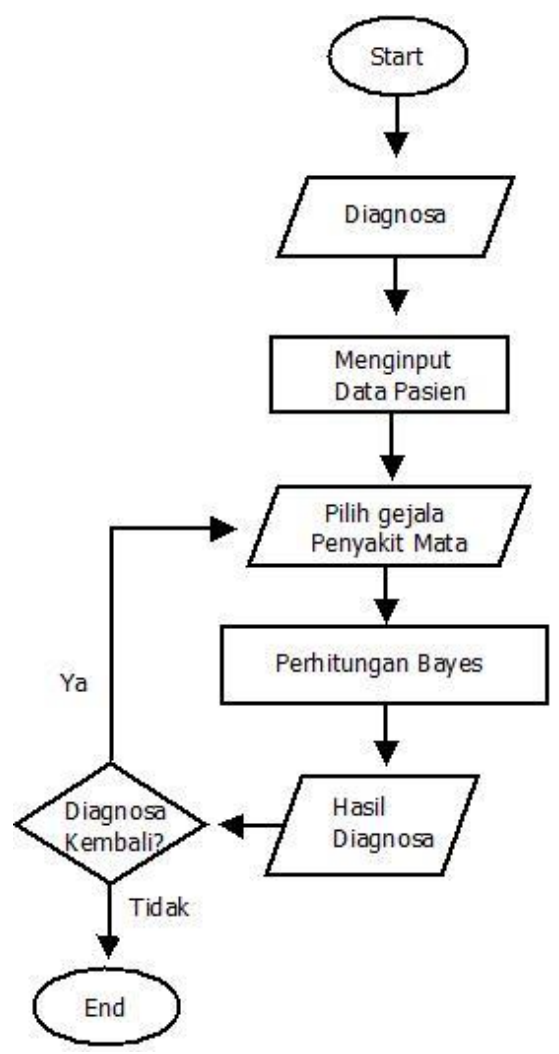

Gambar 2 Desain Flowchart Sistem (Sumber: Hasil Olahan Peneliti) 
b. Data Flow Diagram pada penelitian ini dibangun dengan tiga entitas utama yaitu admin/pakar, operator, dan pasien. Dimana setiap entitas ini beriteraksi dengan sistem dan mempunyai hak akses dalam menginput maupun mendapat informasi data. Data Flow Diagram dapat dilihat pada Gambar 3.

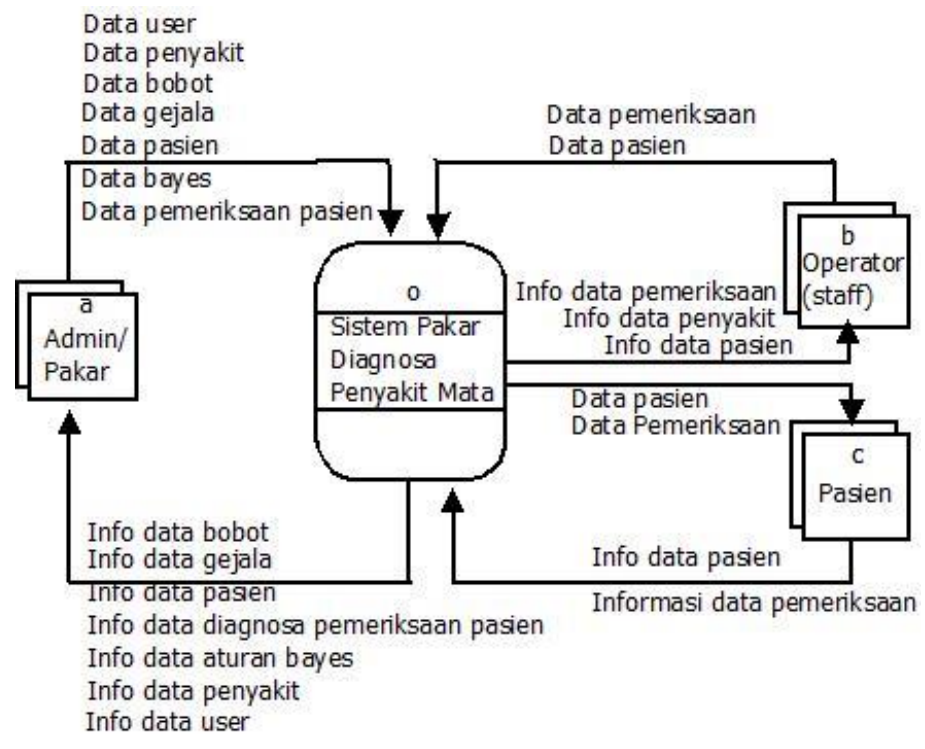

Gambar 3 Rancangan DFD (Sumber: Hasil Olahan Peneliti)

c. Penulisan kode program yaitu implementasi data yang akan diterjemahkan kedalam sistem pakar diagnosa penyakit mata.

d. Pengujian sistem digunakan untuk menguji kecocokan data berdasarkan diagnosa pakar/dokter dengan sistem yang telah dibuat.

\section{HASIL DAN PEMBAHASAN}

Sebagai sampel akan digunakan data dari salah satu pasien dengan perhitungan manual menggunakan perhitungan teorema bayes untuk mendiagnosa penyakit mata. Seorang pasien (LHJ) mengalami gejala mata kabur seperti berkabut dan silau.

Langkah-langkah penyelesaiannya seperti pada persamaan 2

a. Rule gejala yang dipilih pasien (LHJ)

- Gejala 14 pada rule penyakit 4

- Gejala 13 dan gejala 14 pada rule penyakit 5

b. Nilai yang diberikan pakar pada masing-masing gejala dapat dilihat pada Tabel 4 .

Tabel 4 Nilai Pakar

\begin{tabular}{ccc}
\multicolumn{3}{c}{ Tabel 4 Nilai Pakar } \\
\hline Gejala & Nilai Pakar & Nama Penyakit \\
\hline (Gj14) & 0.1 & Pterygium \\
$($ Gj13) & 0.78 & Katarak \\
$($ Gj14) & 0.2 & \\
\hline
\end{tabular}

c. Perhitungan bayes

Perhitungan bayes terhadap penyakit 4 (Pterygium)

» Mencari nilai semesta dengan menjumlahkan nilai gejala pada penyakit

Nilai semesta: $0.1=0.1$

» Menghitung nilai semesta $\mathrm{P}(\mathrm{Hi})$

$\mathrm{P}(\mathrm{H} 1): 0.1 / 0.1=1$

» Menghitung probabilitas $\mathrm{H}$ tanpa memandang evidence apapun

$\mathrm{P}(\mathrm{H} 1) * \mathrm{P}(\mathrm{E} \mid \mathrm{H} 1): 1 * 0.1=0.1$

Total $\mathrm{H}($ Hipotesa $)=0.1$

» Mencari nilai $\mathrm{P}(\mathrm{Hi} \mid \mathrm{E})$

$\mathrm{P}(\mathrm{H} 1 \mid \mathrm{E})=(\mathrm{P}(\mathrm{H} 1) * \mathrm{P}(\mathrm{E} \mid \mathrm{H} 1)) / \mathrm{H}: 1 * 0.1 / 0.1=1$ 
» Menghitung nilai bayes

Nilai bayes : $(0.1 * 1)=0.1$

Dengan demikian hasil perhitungan bayes untuk rule gejala yang telah dipilih oleh pasien memperoleh hasil sebesar 0.1 atau $10 \%$ menderita penyakit pterygium.

Perhitungan bayes terhadap penyakit 5 (Katarak)

» Mencari nilai semesta dengan menjumlahkan nilai gejala pada penyakit

Nilai semesta: $0.78+0.2=0.98$

» Menghitung nilai semesta $\mathrm{P}(\mathrm{Hi})$

$\mathrm{P}(\mathrm{H} 1): 0.78 / 0.98=0.795918367$

$\mathrm{P}(\mathrm{H} 2): 0.2 / 0.98=0.204081633$

» Menghitung probabilitas $\mathrm{H}$ tanpa memandang evidence apapun

$\mathrm{P}(\mathrm{H} 1) * \mathrm{P}(\mathrm{E} \mid \mathrm{H} 1): 0.795918367 * 0.78=0.620816327$

$\mathrm{P}(\mathrm{H} 1) * \mathrm{P}(\mathrm{E} \mid \mathrm{H} 2): 0.204081633 * 0.2=0.040816327$

Total H $($ Hipotesa $)=0.661632653$

» Mencari nilai $\mathrm{P}(\mathrm{Hi} \mid \mathrm{E})$

$\mathrm{P}(\mathrm{H} 1 \mid \mathrm{E})=(\mathrm{P}(\mathrm{H} 1) * \mathrm{P}(\mathrm{E} \mid \mathrm{H} 1)) / \mathrm{H}: 0.795918367 * 0.78 / 0.661632653=0.938309685$

$\mathrm{P}(\mathrm{H} 2 \mid \mathrm{E})=(\mathrm{P}(\mathrm{H} 2) * \mathrm{P}(\mathrm{E} \mid \mathrm{H} 2)) / \mathrm{H}: 0.204081633 * 0.2 / 0.661632653=0.061690315$

$\gg$ Menghitung nilai bayes

$(0.78 * 0.938309685)+(0.2 * 0.061690315)=0.744219618$

Dengan demikian hasil perhitungan bayes untuk rule gejala yang telah dipilih oleh pasien memperoleh hasil sebesar 0.744 atau $74,4 \%$ menderita penyakit katarak.

Berdasarkan pada perhitungan dan pengujian yang telah dilakukan pada gejala penyakit mata yang dipilih oleh pasien (LHJ) menggunakan metode teorema bayes, maka diperoleh pobabilitas nilai bayes tertinggi pada penyakit 5 dengan presentase hasil sebesar 74,4\%. Dengan demikian berdasarkan gejala yang dipilih, penderita atau pasien mengalami penyakit mata katarak. Berikut merupakan tampilan sistem pakar diagnosa penyakit mata dalam menghitung rule gejala pasien LHJ menggunakan metode teorema bayes dapat dilihat pada Gambar 4.

\begin{tabular}{|c|c|c|c|c|c|}
\hline \multicolumn{6}{|c|}{$\begin{array}{l}\text { IF GJ14 }=0.1 \text { THEN Pterygium } \\
\text { IF GJ13 }=0.78 \text { IF GJ14 }=0.2 \text { THEN Katarak }\end{array}$} \\
\hline \multicolumn{6}{|c|}{ Nilai Semesta $=0.1 \&$ Nilai $\mathrm{P}(\mathrm{Hi} \mid \mathrm{E})$ Probabilitas Evidence Pterygium $=0.100$} \\
\hline & Bobot & bobot/ns (P(Hi)) & $P(H i)^{*} P(E \mid H i-n)$ & $\mathrm{P}(\mathrm{Hi} \mid \mathrm{E})$ & Bayes \\
\hline $\mathrm{P}(\mathrm{H} \mid \mathbf{1})$ & 0.1 & 1.000 & 0.100 & $0.1^{*} 1.000 / 0.100=1.000$ & 0.100 \\
\hline \multicolumn{5}{|c|}{ Nilai Bayes } & 0.100 \\
\hline \multicolumn{6}{|c|}{ Nilai Semesta $=0.98 \&$ Nilai $\mathrm{P}(\mathrm{Hi} \mid \mathrm{E})$ Probabilitas Evidence Katarak $=0.662$} \\
\hline & Bobot & bobot/ns $(\mathrm{P}(\mathrm{Hi}))$ & $\mathbf{P}(\mathrm{Hi})^{\star} \mathrm{P}(\mathrm{E} \mid \mathrm{Hi}-\mathrm{n})$ & $\mathrm{P}(\mathrm{Hi|} \mathrm{E})$ & Bayes \\
\hline $\mathrm{P}(\mathrm{H} \mid \mathbf{1})$ & 0.78 & 0.796 & 0.621 & $0.78^{\star} 0.796 / 0.662=0.938$ & 0.732 \\
\hline $\mathrm{P}(\mathrm{H} \mid 2)$ & 0.2 & 0.204 & 0.041 & $0.2^{*} 0.204 / 0.662=0.062$ & 0.012 \\
\hline \multicolumn{5}{|c|}{ Nilai Bayes } & 0.744 \\
\hline
\end{tabular}

Gambar 4 Halaman Perhitungan Sistem

\subsection{Validasi Hasil}

Hasil validasi data ini menunjukkan seberapa besar presentase yang didapatkan berdasarkan data hasil uji rekam medis pasien terhadap gejala penyakit mata hordeolum, mata kering, episkleritis, pterygium, dan katarak. Hasil pengujian ini juga menunjukkan validasi kesesuaian antara perhitungan sistem menggunakan metode teorema bayes dengan hasil diagnosa pakar. Hasil uji validasi sistem pakar diagnosa penyakit mata dapat dilihat pada Tabel 5 . 
Tabel 5 Hasil Validasi

\begin{tabular}{|c|c|c|c|c|c|}
\hline \multirow{2}{*}{ No } & \multirow{2}{*}{ Nama } & \multicolumn{2}{|c|}{ Hasil Perhitungan Sistem } & \multirow{2}{*}{$\begin{array}{l}\text { Hasil Perhitungan } \\
\text { Pakar }\end{array}$} & \multirow{2}{*}{ Validasi } \\
\hline & & Penyakit & Presentase & & \\
\hline 1 & MVH & Hordeolum & $60,8 \%$ & Hordeolum & Sesuai \\
\hline 2 & RRT & Hordeolum & $60,8 \%$ & Hordeolum & Sesuai \\
\hline 3 & RDP & Hordeolum & $62,3 \%$ & Hordeolum & Sesuai \\
\hline 4 & VI & Hordeolum & $63,3 \%$ & Hordeolum & Sesuai \\
\hline 5 & GW & Hordeolum & $63,3 \%$ & Hordeolum & Sesuai \\
\hline 6 & GB & Hordeolum & $60,8 \%$ & Hordeolum & Sesuai \\
\hline 7 & SHL & Hordeolum & $60,2 \%$ & Hordeolum & Sesuai \\
\hline 8 & BDK & Hordeolum & $59,7 \%$ & Hordeolum & Sesuai \\
\hline 9 & AW & Hordeolum & $60,8 \%$ & Hordeolum & Sesuai \\
\hline 10 & SDM & Hordeolum & $60,8 \%$ & Hordeolum & Sesuai \\
\hline 11 & RRA & Mata Kering & $65,9 \%$ & Mata Kering & Sesuai \\
\hline 12 & M & Mata Kering & $65,9 \%$ & Mata Kering & Sesuai \\
\hline 13 & $\mathrm{~S}$ & Mata Kering & $65,9 \%$ & Mata Kering & Sesuai \\
\hline 14 & WH & Pterygium & $25 \%$ & Mata Kering & $\begin{array}{l}\text { Tidak } \\
\text { Sesuai }\end{array}$ \\
\hline 15 & EW & Mata Kering & $65,9 \%$ & Mata Kering & Sesuai \\
\hline 16 & $S$ & Mata Kering & $65,6 \%$ & Mata Kering & Sesuai \\
\hline 17 & EI & Mata Kering & $65,9 \%$ & Mata Kering & Sesuai \\
\hline 18 & ESI & Mata Kering & $66,2 \%$ & Mata Kering & Sesuai \\
\hline 19 & $\mathrm{~S}$ & Mata Kering & $65,9 \%$ & Mata Kering & Sesuai \\
\hline 20 & TRH & Mata Kering & $65,9 \%$ & Mata Kering & Sesuai \\
\hline 21 & API & Episkleritis & $56 \%$ & Episkleritis & Sesuai \\
\hline 22 & FW & Episkleritis & $58,6 \%$ & Episkleritis & Sesuai \\
\hline 23 & $\mathrm{~K}$ & Episkleritis & $58,6 \%$ & Episkleritis & Sesuai \\
\hline 24 & K & Pterygium & $25 \%$ & Episkleritis & $\begin{array}{l}\text { Tidak } \\
\text { Sesuai }\end{array}$ \\
\hline 25 & UU & Episkleritis & $56 \%$ & Episkleritis & Sesuai \\
\hline 26 & MHD & Episkleritis & $54,8 \%$ & Episkleritis & Sesuai \\
\hline 27 & RMZ & Episkleritis & $56 \%$ & Episkleritis & Sesuai \\
\hline 28 & MDD & Episkleritis & $54,8 \%$ & Episkleritis & Sesuai \\
\hline 29 & KFM & Episkleritis & $57,3 \%$ & Episkleritis & Sesuai \\
\hline 30 & MA & Episkleritis & $54,8 \%$ & Episkleritis & Sesuai \\
\hline 31 & RT & Pterygium & $42,9 \%$ & Pterygium & Sesuai \\
\hline 32 & IGHD & Pterygium & $42,9 \%$ & Pterygium & Sesuai \\
\hline 33 & $S$ & Pterygium & $42,9 \%$ & Pterygium & Sesuai \\
\hline 34 & $\mathrm{~N}$ & Pterygium & $42,9 \%$ & Pterygium & Sesuai \\
\hline 35 & $\mathrm{~S}$ & Pterygium & $42,9 \%$ & Pterygium & Sesuai \\
\hline 36 & $\mathrm{~S}$ & Pterygium & $50 \%$ & Pterygium & Sesuai \\
\hline 37 & UK & Pterygium & $50 \%$ & Pterygium & Sesuai \\
\hline 38 & RS & Pterygium & $50 \%$ & Pterygium & Sesuai \\
\hline 39 & $\mathrm{~S}$ & Pterygium & $45,7 \%$ & Pterygium & Sesuai \\
\hline 40 & MSL & Pterygium & $45 \%$ & Pterygium & Sesuai \\
\hline 41 & YS & Katarak & $73,3 \%$ & Katarak & Sesuai \\
\hline 42 & LHJ & Katarak & $74,4 \%$ & Katarak & Sesuai \\
\hline 43 & W & Katarak & $74,4 \%$ & Katarak & Sesuai \\
\hline 44 & $\mathrm{P}$ & Katarak & $78 \%$ & Katarak & Sesuai \\
\hline 45 & SS & Katarak & $78 \%$ & Katarak & Sesuai \\
\hline 46 & SS & Katarak & $78 \%$ & Katarak & Sesuai \\
\hline 47 & $\mathrm{Q}$ & Katarak & $74,4 \%$ & Katarak & Sesuai \\
\hline 48 & $\mathrm{~N}$ & Katarak & $78 \%$ & Katarak & Sesuai \\
\hline 49 & $\mathrm{~N}$ & Katarak & $78 \%$ & Katarak & Sesuai \\
\hline 50 & AFM & Katarak & $74,2 \%$ & Katarak & Sesuai \\
\hline
\end{tabular}




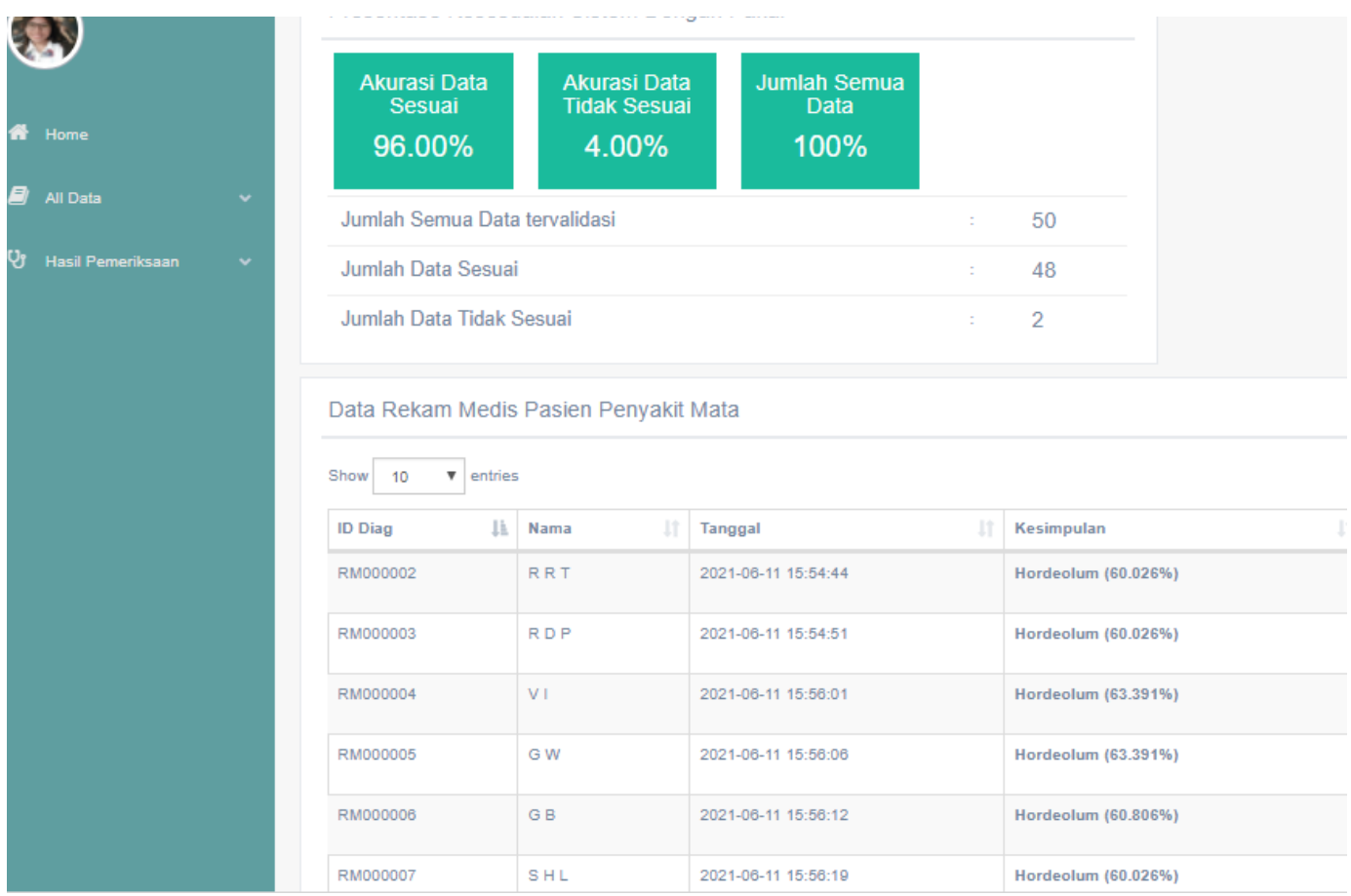

Gambar 5 Halaman Hasil Pemeriksaan Pasien

Halaman pemeriksaan pasien merupakan hasil dari pemeriksaan berupa diagnosa penyakit mata seluruh pasien dengan presentase perhitungan pada masing-masing gejala pada penyakit mata yang ada pada halaman frond end sistem. Terdapat 50 data rekam medis pasien yang telah diujikan. Dengan validasi keseuaian sebanyak 48 data, dan ketidaksesuaian sebanyak 2 data. Halaman hasil pemeriksaan pasien dapat dilihat pada Gambar 5.

\section{KESIMPULAN}

Berdasarkan pada penelitian yang telah dilakukan, dapat disimpulkan bahwa sistem pakar dengan metode teorema bayes yang telah dibuat dapat diimplementasikan dalam membantu keperluan medis dalam mendiagnosa penyakit mata yaitu penyakit hordeolum, mata kering, episkleritis, pterygium, dan katarak. Dengan hasil validasi kesesuaian antara hasil pakar dan hasil sistem sebesar $96 \%$ data.

\section{DAFTAR PUSTAKA}

[1] S. Kusumadewi, Artificial Intelligence, Yogyakarta: Graha Ilmu, 2003.

[2] R. Jannah, Segala Gangguan Dan Penyakit Mata, Yogyakarta: Guepedia, 2010.

[3] A. W. O. Gama, I. W. Sukadana dan G. H. Prathama, "Sistem Pakar Diagnosa Awal Penyakit Mata (Penelusuran Gejala dengan Metode Backward Chaining),” J-Eltrik, Vol. 1, No. 2, ISSN : 2656-9396, pp. 71-76, 2019.

[4] M. H. Qamaruzzaman dan S., "Sistem Pakar Untuk Mendiagnosa Penyakit Mata Pada Manusia Menggunakan Teorema Bayes," Indonesian Journal on Networking and Security, Vol. 5, No. 4, ISSN : 2354-6654, pp. 7-11, 2016.

[5] Y. Permana, I. G. P. S. Wijaya dan F. Bimantoro, "Sistem Pakar Diagnosa Penyakit Mata Menggunakan Metode Certainty Factor Berbasis Android," J-COSINE, Vol. 1, No. 1, ISSN : 2541-0806, pp. 1-10, 2017.

[6] N. Sulardi dan A. Witanti, "Sistem Pakar Diagnosis Penyakit Anemia Menggunakan Teorema Bayes," Jurnal Teknik Informatika (Jutif), Vol. 1, No. 1, ISSN : 2723-3871, pp. 19-24, 2020.

[7] N. Umayah, I. F. Astuti dan S. Maharani, "Sistem Pakar Untuk Mendiagnosa Penyakit Pada Tanaman Kakao Menggunakan Metode Teorema Bayes," Prosiding Seminar Nasional Ilmu Komputer dan Teknologi Informasi, Vol. 3, No. 2, ISSN : 2540-7902, pp. 72-75, 2018.

[8] M. Arhami, Konsep Dasar Sistem Pakar, Yogyakarta: Andi, 2005. 
[9] A. Amborowati dan N. Hidayah, "Analisis Dan Perancangan Sistem Pakar Diagnosa Penyakit Mematikan Pada Perempuan Menggunakan Metode Bayes (Studi Kasus : Asri Medical Center)," Seminar Nasional Teknologi Informasi dan Multimedia, ISSN : 2302-3805, pp. 1-6, 2016.

[10] A. M. Yusuf, Metode Penelitian Kuantitatif, Kualitatif, \& Penelitian Gabungan, Jakarta: Kencana, 2014. 